\title{
Massive Chylothorax Following Gunshot Injury to the Left Supraclavicular Region: Case Report and Literature Review
}

\author{
Abubakar Umar ${ }^{1}$, Salisu Ismail ${ }^{2}$, Abdullahi Abdulkarim Aitek ${ }^{3}$, Aliyu Abdulrahman ${ }^{4}$, \\ Galadima Ibrahim ${ }^{4}$, Maishanu Moyijo ${ }^{2}$ \\ ${ }^{1}$ Cardiothoracic Surgery Unit, Department of Surgery, Usmanu Danfodiyo University / Usmanu Danfodiyo University Teaching Hospital, \\ Sokoto, Nigeria \\ ${ }^{2}$ Cardiothoracic Surgery Unit, Department of Surgery, Usmanu Danfodiyo University Teaching Hospital, Sokoto, Nigeria \\ ${ }^{3}$ Department of Anaesthesiology and Intensive Care, Usmanu Danfodiyo University, Usmanu Danfodiyo University Teaching Hospital, \\ Sokoto, Nigeria \\ ${ }^{4}$ Department of Anaesthesiology and Intensive Care, Usmanu Danfodiyo University Teaching Hospital, Sokoto, Nigeria
}

Email address:

drzuru@yahoo.com (A. Umar)

\section{To cite this article:}

Abubakar Umar, Salisu Ismail, Abdullahi Abdulkarim Aitek, Aliyu Abdulrahman, Galadima Ibrahim, Maishanu Moyijo. Massive Chylothorax Following Gunshot Injury to the Left Supraclavicular Region: Case Report and Literature Review. International Journal of Cardiovascular and Thoracic Surgery. Vol. 5, No. 1, 2019, pp. 18-20. doi: 10.11648/j.ijcts.20190501.14

Received: December 24, 2018; Accepted: January 21, 2019; Published: May 8, 2019

\begin{abstract}
Chylothorax is defined as accumulation of chyle in the pleural space. Various aetiologies have been identified. Direct injury to the thoracic duct following gunshot injury is rare. When it occurs close to the point of entry into the confluence of the internal jugular and subclavian veins, it can lead to massive chylothorax with devastating consequences. A case of gunshot to the root of the neck with massive chylothorax with haemodynamic instability is hereby presented.
\end{abstract}

Keywords: Chylothorax, Gunshot Injury, Thoracic Duct

\section{Introduction}

Chylothorax is defined as accumulation of chyle in the pleural space. Over 2 litres of chyle is said to be transported daily through the lymphatic channels. Therefore, damage or rupture of the thoracic duct can lead to massive accumulation of these fluid in the pleural space leading to haemodynamic and respiratory compromise [1-4]. Aetiologies of chylothorax has been classified as either traumatic or non-traumatic. The traumatic type causes direct damage to the duct which will lead to instant leakage in chyle or by damage to surrounding tissues around the duct that may result in inflammation and compression of the duct leading to blockage of the duct which will subsequently lead to rupture. Thoracic surgery is now said to be the leading cause of traumatic chylothorax with oesophageal surgery leading the way [5-7]. Penetrating chest injuries account for $0.2-3 \%$ of cases [8-9]. We present a case of gunshot injury to the left supraclavicular region with massive chylothorax which was refractory to resuscitation and conservative management.

\section{Case Report}

A 20-year-old man who was shot at the left supraclavicular region at a close range, was said to have bleed at the scene of the incidence. Patient was rushed to a near-by hospital where he had a chest tube inserted which initially drained blood and air and subsequently kept on draining yellowish-milky fluid. Average drainage in $24 \mathrm{hrs}$ was in excess of 2 litres. The patient was referred to our unit for further evaluation and management. At presentation he was in hypovolaemic shock and was immediately resuscitated and had a $0.5 \mathrm{~cm}$ entry wound and about $1 \mathrm{~cm}$ exit wound posterior to the neck. Within 24 hours on admission he drained about 2.2litres and went into hypovolaemic shock in which he was also resuscitated. Chest X-ray showed homogenous opacity of the left hemithorax with mediastinal shift to the right (see Figure $1)$. 


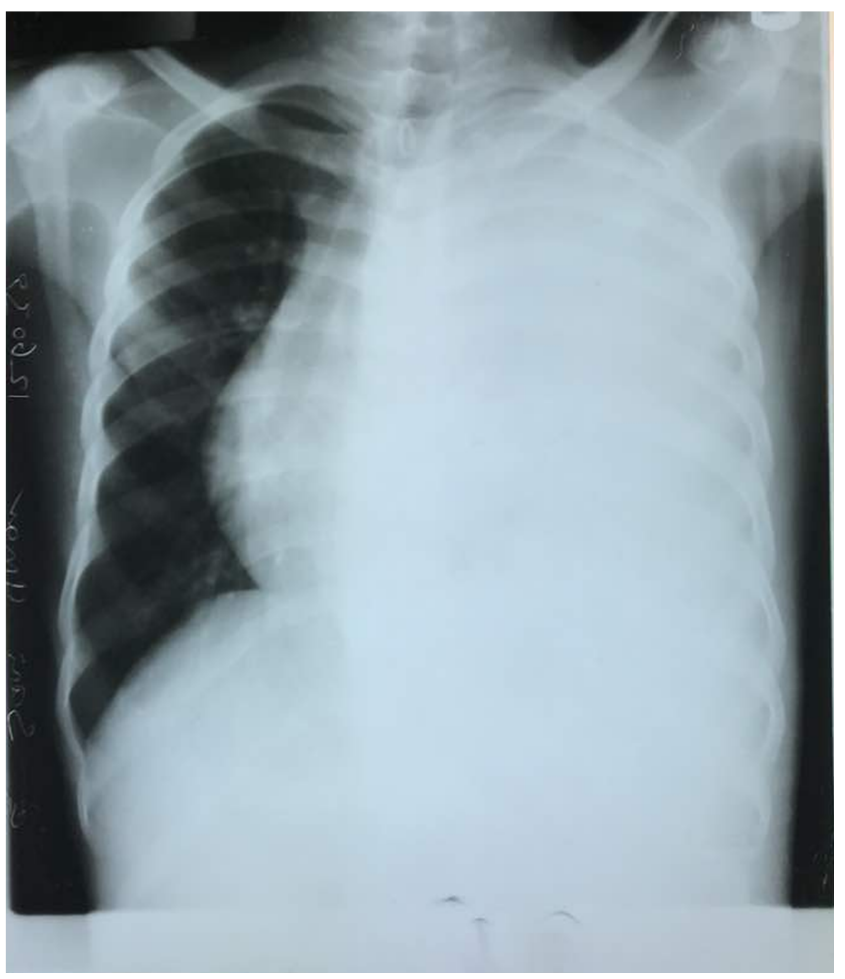

Figure 1. Chest X-ray.

A diagnosis of post-traumatic high output chylothorax was made. He was kept on nil by mouth, intravenous fluid and antibiotics. Pleural fluid sample was sent for analysis and triglyceride was $183 \mathrm{mmol} / \mathrm{L}$. Had pleurodesed with tetracycline but there was no reduction in output. He was prepared for thoracotomy and ligation of the thoracic duct. Intraoperatively massive chylous effusion with residual tetracycline debri within the pleural cavity was discovered (see Figure 2).

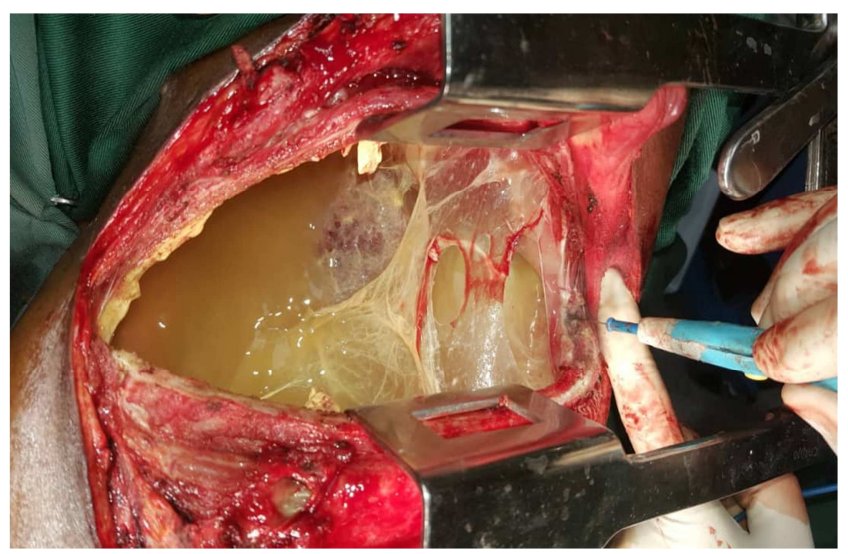

Figure 2. After thoracotomy-massive chylothorax.

Exploration revealed an opening close to the point of entry of the thoracic duct into the junction between left subclavian and left internal jugular veins which was continuously draining chylous fluid (see Figure 3).

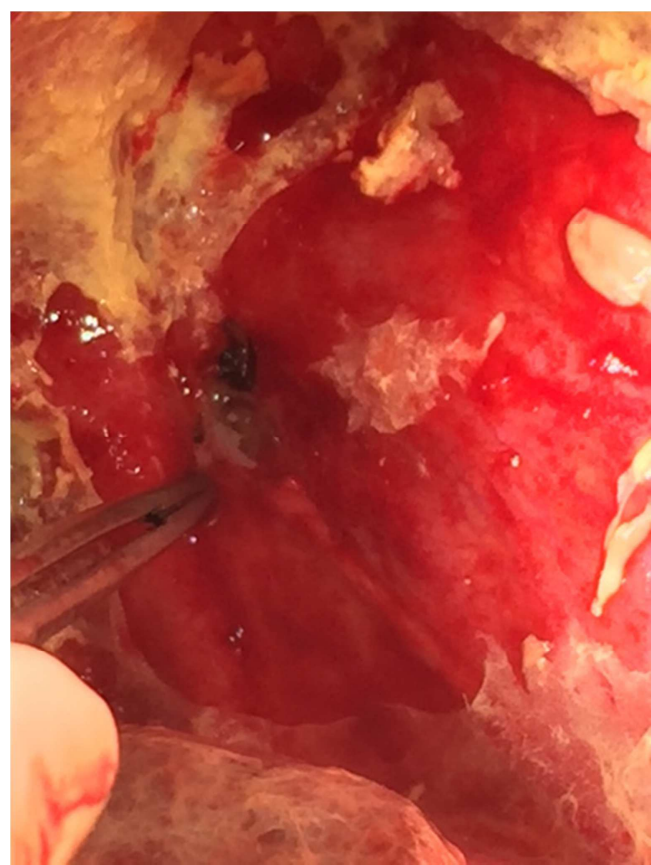

Figure 3. Artery forceps showing the point of injury.

Opening of the duct was ligated with surrounding tissues and fluid was noticed to have stopped draining. The pleural cavity was copiously irrigated with warm saline and thoracotomy wound closed in layers. Post-operative fluid drainage remained less than $100 \mathrm{mls} / 24 \mathrm{hrs}$ of serous fluid and chest tube was removed on the $4^{\text {th }}$ day post-op. He was discharged on the $7^{\text {th }}$ day post-op. He was seen in the outpatient clinic in stable clinical condition.

\section{Discussion}

Isolated thoracic duct injury without any major vascular or tracheobronchial injury is said to be rare [10-12]. Even where it occurs, it is said to be overshadowed by other injuries intrathoracic injuries [13]. Worthington et al [9] reported an incidence of $0.06 \%$ in their series over a 13 -year period. Our patient had a gunshot injury to the thoracic duct close to its entry into the confluence of the subclavian vein and internal jugular vein. The bullet miraculously missed most of the structures in the neck. He presented with massive drainage which is not surprising as this is the point of maximum amount of chyle, therefore, injury at this level is likely to lead to high output chylothorax. This massive drainage predisposed him to hypovolaemic shock twice under our care. The initial approach to chylothorax is conservative management which entails placing a chest tube to drain the pleural space, nil by mouth, medium chain triglyceride administration by mouth and institution of total parenteral nutrition if above measures fail. These has been reported to reduce the flow of chyle thereby allowing healing to occur $[1,14]$. Our patient was initially placed on nil by mouth and chest drainage but never showed any sign of improvement as such we opted to pleurodese him which has been advocated by some authors [15-17]. This also did not lead to reduction 
in the drainage. For pleurodesis to be effective, it is important that full lung re-expansion is achieved after draining the fluid [18]. With this massive amount of fluid draining, it will be difficult to achieve full lung re-expansion as such the pleurodesis failed. The optimum time for surgical intervention is still not clear, some authors advocate persistent drainage of 2 weeks while others advocate one week [19-20]. The patient had surgery after 2 weeks of nonoperative management with no significant improvement. We did a thoracotomy and ligated the duct close to the point of injury (close to the point of entry). We were able to achieve this because we could identify the duct at this level. At around this level it is advocated that ligation can be carried out at Poirier's triangle through a left thoracotomy [1, 21-22]. Our patient had an uneventful recovery and was subsequently discharged.

\section{Conclusion}

It was concluded that patients with thoracic duct injuries close to the entry of the thoracic duct into the internal jugular vein can have massive chylothorax that is likely to be refractory to conservative management and pleurodesis as such early surgical intervention is indicated. There is need for further research to ascertain the amount of drainage at presentation that will warrant urgent surgical intervention and to determine acceptable time to abandon conservative management.

\section{References}

[1] McGrath EE, Blades Z, Anderson PB. Chylothorax: aetiology, diagnosis and therapeutic option. Respiratory Medicine. 2010;104:1-8.

[2] Bessone LN, Ferguson TB, Burford TH. Chylothorax. Ann Thorac Surg 1971; 12 (5): 527-50.

[3] Nair SK, Petko M, Hayward MP. Aetiology and management of chylothorax in adults. Eur J Cardiothorac Surg. 2007; 32: 362-9.

[4] Fairfax AJ, McNabb WR, Spiro SG. Chylothorax: a review of 18 cases. Thorax 1986; 41: 880-5.

[5] Pillay TG, Singh B. A review of traumatic chylothorax. Injury. 2016; 47 (3): 545-50.

[6] Orringer MB, Bluett M, Deeb GM. Aggressive treatment of chylothorax complicating transhiatal esophagectomy without thoracotomy. Surgery 1988; 104 (4): 720e6.
[7] Cestero J, Bukhary H, Carrillo E, Rosenthal H, Pepe A, Sanchez R, Lee SK. Refractory chylothorax following a transhepatic gunshot wound to the abdomen requiring unorthodox surgical treatment. J Surg Case Rep. 2010; (6): 3.

[8] Doerr CH, Allen MS, Nichols FC, Ryu JH. Etiology of chylothorax in 203 patients. Mayo Clin Proc 2005; 80: 867870.

[9] Servelle M, et al. Spontaneous, post-operative and trau- matic chylothorax. J Cardiovasc Surg (Torino) 1980; 21 (4): 475-86.

[10] Worthington MG, et al. Isolated thoracic duct injury after penetrating chest trauma. Ann Thorac Surg 1995; 60 (2): 2724.

[11] Carrillo Esper R, Sosa-Garcia JO, Carrillo-Cordova CA. chylothorax secondary to gunshot wound. Cir Cir. 2009; 77 (6): 447-449.

[12] Sendama W, Shipley M. Traumatic chylothorax: A case report and review. Respir Med Case Rep. 2015; 14: 47-8.

[13] Grant PW, Brown SW. Traumatic chylothorax: a case report. Aust N Z J surg report. 1991; 61: 798-800.

[14] De Beer HG, Mol MJ, Janssen JP. Chylothorax. Neth J Med 2000; 56 (1): 25-31.

[15] Philippakis GE, Moustardas MP. Successful pleurodesis for refractory chylothorax due chronic lymphocytic leukaemia. Int J Sur Case Rep. 2012; (3): 167-169.

[16] Rizzardi G, et al. Persistent chylothorax in lymphangioleiomyomatosis treated by intrapleural instillation of povidone. Eur J Cardiothorac Surg 2008; 34 (1): 214-5.

[17] Weissberg D, Ben-Zeev I. Talc pleurodesis. Experience with 360 patients. J Thorac Cardiovasc Surg 1993; 106 (4): 689-95.

[18] Villanueva AG, Gray AW, Jr., Shahian DM, Williamson WA, Beamis JF., Jr. Efficacy of short term versus long term tube thoracostomy drainage before tetracycline pleurodesis in the treatment of malignant pleural effusions. Thorax. 1994; 49(1): $23-25$.

[19] Selle JG, Snyder WH III, Schreiber JT. Chylothorax: indication for surgery. Ann Surg 1973; 177: 245-9.

[20] Mason PF, Thorpe JAC. Chylothorax: a new surgical strategy [letter]. Chest 1993; 103: 1929.

[21] Nalukurthi SC, Kishore J, Samarasam I, Gnanamuthu BR, Paul MJ. Chyolothorax following thyroid surgery: A report of two cases and review of management strategies. World $\mathrm{J}$ Endoc Surg; 6 (3): 115-118.

[22] Allison S, Rainey M, Aarabi S, et al. Traumatic laceration of the cisterna chyli treated by lymphangiography and percutaneous embolization. Cardiovasc Intervent Radiol. 2014; 37 (1): 267-70. 